\title{
Credit card spending limit and personal finance: system dynamics approach
}

\author{
Mirjana Pejić Bach ${ }^{1, *}$, Jovana Zoroja ${ }^{2}$ and Marjana Merkač Skok ${ }^{3}$ \\ ${ }^{1}$ Department of Informatics, Faculty of Economics and Business, University of Zagreb \\ Trg J.F. Kennedya 6, HR-10000 Zagreb, Croatia \\ E-mail: 〈mpejic@efzg.hr $\rangle$ \\ ${ }^{2}$ Department of Informatics, Faculty of Economics and Business, University of Zagreb \\ Trg J.F. Kennedya 6, HR-10000 Zagreb, Croatia \\ E-mail: 〈jzoroja@efzg.hr〉 \\ ${ }^{3}$ Fakulteta za poslovne in komercijalne vede, Celje \\ Lava 7, SL-3000 Celje, Slovenia \\ E-mail:〈marjana.merkac@fkpv.si〉
}

\begin{abstract}
Credit cards have become one of the major ways for conducting cashless transactions. However, they have a long term impact on the well being of their owner through the debt generated by credit card usage. Credit card issuers approve high credit limits to credit card owners, thereby influencing their credit burden. A system dynamics model has been used to model behavior of a credit card owner in different scenarios according to the size of a credit limit. Experiments with the model demonstrated that a higher credit limit approved on the credit card decreases the budget available for spending in the long run. This is a contribution toward the evaluation of action for credit limit control based on their consequences.
\end{abstract}

Key words: credit card, credit limit, system dynamics

Received: September 23, 2013; accepted: February 4, 2014; available online: March 12,2014

\section{Introduction}

Credit cards have become a way of life [9] as well as an important part of the modern society. In five years, from 1999 to 2005, the annual volume of credit card transactions has doubled [1]. However, differences exist between developed and developing countries in their usage and their owners' behavior [19]. Citizens of more developed countries use credit cards more both in terms of the number and the quantity of transactions.

Nowadays, credit cards are considered as important as cash; some believe that they lead to a cashless society [9]. At the beginning of the $21^{s t}$ century more than a billion credit cards of all types were issued in the USA, which is the consequence of weakened requirements for getting them and an increasing number of college

${ }^{*}$ Corresponding author. 
students who own at least one credit card [12]. Financial institutions also apply very aggressive marketing of credit cards in order to increase their use, especially by the usage of customer relationship management (CRM) [7]. However, credit card owners' typical behavior has a significant impact on bank risk exposure at default (EAD), which can be defined as the gross exposure under a facility upon default, and it is at the Basel 2 level [10].

Marketing departments of financial institutions are trying to attract college students to use credit cards because they usually continue using them after they graduate [9]. Students' attitude toward credit card usage can be explained by several factors: ethnic background, gender, living arrangement, parent's credit card use and the number of credit cards owned, education level, money ethic and self-control $[6,11]$.

There are also consumers who have credit cards but they do not use them; they are called inactive users. Factors such as economic and demographic or attitudinal characteristics can be used to identify active or inactive credit card users [26]. According to [5], active credit card users are those who use a credit card more than 10 times during one month, and those who use it less than ten times in one month are inactive credit card users.

Income, as one of the demographic variables, is the most important variable that influences the card usage rate [5] as well as age and education [1]. Other authors emphasize that social classes affect purchase [24]. According to research, males use credit cards more than females [1].

There is a difference in the behavior of credit card users according to their social class [25]. Those in a lower social class use credit cards more frequently and mostly for installment purposes and those in an upper social class use them for convenience. People from a lower social class use credit cards for necessity goods, and people from an upper social class use them to purchase luxury goods [2]. Similar results can be found in the study conducted by Danes et al. [8]. According to age, older respondents believe that credit cards should be used for convenience, while highly educated respondents believe that installment is the reason for using credit cards more frequently.

Soman and Cheema [22] made several experiments about the effect of credit on a spending decision and they found that a higher credit limit on credit card spending increases spending especially for some groups of users (younger consumers and less educated consumers). The study of credit card debt among college students showed interesting results $[17,18]$. Students borrow the money with the expectation that they will repay their debt by means of income from their first or second job after graduation. However, in some cases, this leads to an unsuccessful ability to manage and understand the financial situation.

Simulation modelling and especially its method of system dynamics is widely used for modeling social systems due to many factors and an unpredicted situation we are faced with in everyday life, and they are also used for achieving business excellence in organizations $[15,16]$. System dynamics models are also used as a basis for development of simulation games [27]. Previous research did not investigate the behavior of credit card users with system dynamics modeling, and this research gap will be filled with our paper. 
The objective of the paper is to study the impact of the credit card limit on the long-term budget available for spending with the usage of the system dynamics approach, with the presumption that a higher credit limit on credit card spending will decrease the long-term budget available for spending [18, 22]. To test this presumption, we used a system dynamics model of the credit card impact on the budget available for spending, which is developed by Ratha [20] as part of the Road Maps program. Our experiments included different levels of credit limits and captured the behavior of credit card owners by Ratha's model during the simulated period of 72 months.

The paper is organized as follows. After the introductory part of the paper, Section two presents the methodology of the paper. Section three presents the system dynamics model of credit card usage. In Section four, model behavior with different values of the credit limit is described. Section five presents a prototype of the simulation game for credit card usage, and Section six concludes the paper.

\section{Methodology}

Simulation modeling is a methodology used for exploring system behavior and proposing system improvement in several situations, such as investigation of the bullwhip effect using spreadsheet simulation [4], and optimization of flexible assembly systems [13]. System dynamics is a methodology used for modeling long-term behavior of dynamics systems with feedback $[23,3]$.

In order to fullfil the objective of the paper, we conducted a series of experiments with the system dynamics model of credit card owners' behavior developed by Ratha [20] as part of the Road Maps program. While evaluating his model, Ratha [20] found out that the typical behavior of the credit card user leads to short term improvement of the budget available for spending, while in the long run it reduces the budget available for spending. However, Ratha [20] conducted his experiments using only one value for the credit limit (6,000 USD). In order to examine the effect with different levels of the credit limit, we used three different values $(2,000,6,000$ and 12,000 USD). For the purpose of our experiments, we used Vensim software.

Based on the experiments with three different values of the credit limit $(2,000$, 6,000 and 12,000 USD), we evaluated a long-term impact of the credit limit value on the budget available for spending. Experiments were conducted using two models developed by Ratha [20]: a model without repayment and a model with repayment. These models will be explained further in the paper.

\subsection{Model without repayment}

Figure 1 presents the level and rate diagram of the credit card usage system dynamics model without debt repayment. Vensim notations for model equations have been used: levels are written with Capital Letters, rates and auxiliary variables are written with small letters, and constants are written with ALL-CAPS. Such notations will be used throughout the following text.

The model consists on the following equations. There is one level (Balance Payable) and one rate in the model (credit card purchases). INTEG is used as 
a synonym for "integrate" and it indicates that at any moment in time the stock is equal to the sum of all inflows minus the sum of all outflows plus the initial value. Therefore, the Balance Payable is the amount of money the person owes to the Credit Card Company and the initial Balance Payable is set to 0. Credit card purchases refer to the purchase made each month with the money left from the paycheck after making the payments.

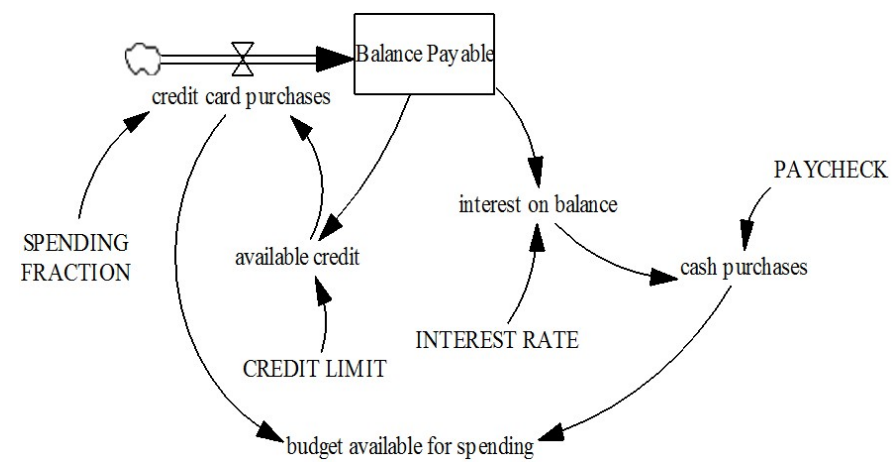

Figure 1: Level-and-rate diagram of credit card usage system dynamics model, Source: Ratha [20]

$$
\begin{gathered}
\text { Balance Payable = INTEG (credit card purchase) } \\
\text { Units }: \text { dollars }
\end{gathered}
$$

$$
\begin{gathered}
\text { Credit card purchases }=\text { SPENDINGFRACTION } \cdot \text { available credit } \\
\text { Units }: \text { dollars/Month }
\end{gathered}
$$

Auxiliary variables in the models are the following: available credit, interest on balance, cash purchases, and budget available for spending. Available credit is the difference between the credit limit and the Balance Payable. The available credit is the maximum amount of money the person can charge to his or her credit card at the time. The interest on balance is the interest charged on person's Balance Payable by the Credit Card Company. Credit card purchases are the amount a person charges on his or her credit card each month, and a fixed fraction, the SPENDING FRACTION of the available credit. The budget available for spending is approximately measured by the total amount of money a person can spend at any time.

$$
\begin{gathered}
\text { Available credit }=\text { CREDIT LIMIT - Balance Payable } \\
\text { Units }: \text { dollars } \\
\begin{aligned}
\text { Interest on balance }=\text { INTEREST RATE B Balance Payable } \\
\text { Units }: \text { dollars/Month }
\end{aligned}
\end{gathered}
$$




$$
\begin{gathered}
\text { Cash purchases }=\text { PAYCHECK - interest on balance } \\
\text { Units }: \text { dollars/Month }
\end{gathered}
$$

Budget available for spending $=$ cash purchases + credit card purchases

$$
\text { Units : dollars/Month }
$$

Model constants are as follows: credit limit, interest rate, paycheck, and spending fraction. Credit limit refers to the maximum amount a person can charge on his or her credit card. It is the maximum value of the Balance Payable. Interest rate is the fraction of the Balance Payable charged as the interest per month. The paycheck is the amount of money a person earns each month. The spending fraction is the fraction of the available credit a person can spend on credit card purchases each month. The following values are set for the model constants.

$$
\begin{gathered}
\text { CREDIT LIMIT = step }(6000,6) \\
\text { Units : dollars } \\
\text { INTEREST RATE = } 0.015 \\
\text { Units : 1/Month } \\
\text { PAYCHECK = } 2000 \begin{array}{c}
\text { Units : dollars/Month } \\
\text { SPENDING FRACTION }=0.1 \\
\text { Units : 1/Month }
\end{array}
\end{gathered}
$$

\subsection{Model with repayment}

Figure 2 presents the level and rate diagram of the credit card usage system dynamics model with the gradual repayment of debt. Level variable Balance Payable has been changed and now its equation is as follows:

$$
\begin{aligned}
& \text { Balance Payable }= \\
& \text { INTEG(credit card purchases + interest charges - payments, } 0) \\
& \text { Units }: \text { dollars }
\end{aligned}
$$

Three auxiliary variables have been added: balance payments, interest charges and payments. Balance payments depend on the credit limit and the spending 


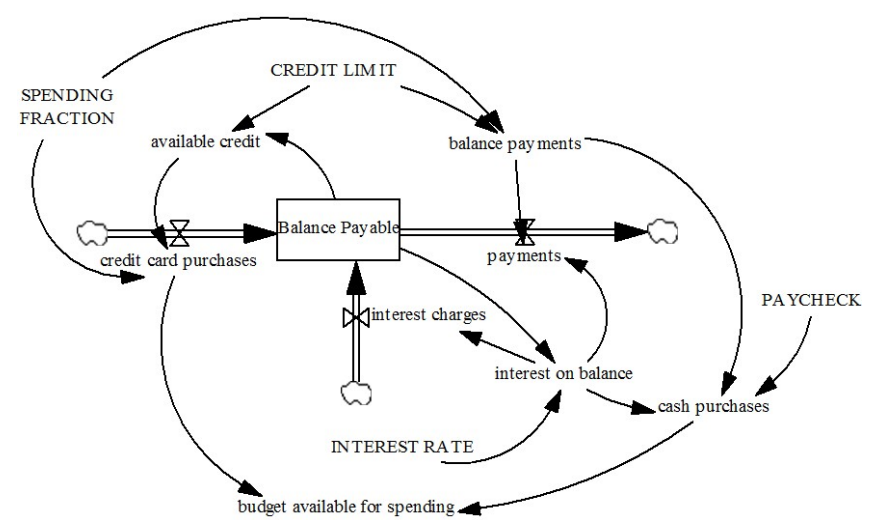

Figure 2: Level and rate diagram of the credit card usage system dynamics model with the gradual repayment of debt, Source: Ratha [20]

fraction, with the initial value of 0 . We presume that an individual starts to repay his or her balance in month 48, and that he or she repays the amount the owner would spend on his or her credit card every month if his or her balance payment is zero. This period is used as a presumption that the credit card owner is a student who repays his or her debt after graduation. Interest charges are the interest charged each month on the Balance Payable. The payments represent the amount of money that an individual pays to the Credit Card Company, and it includes both interest on balance and balance payments.

$$
\begin{gathered}
\text { Balance payments }=\operatorname{step}(C R E D I T L I M I T \cdot S P E N D I N G F R A C T I O N, 48) \\
\text { Units }: \text { dollars/Month }
\end{gathered}
$$

Interest charges $=$ interest on balance

$$
\text { Units : dollars/Month }
$$

$$
\begin{gathered}
\text { Payments }=\text { interest on balance }+ \text { balance payments } \\
\text { Units }: \text { dollars/Month }
\end{gathered}
$$

\section{Model behavior and results}

In this section model behavior of two system dynamics models of credit card usage will be presented.

\subsection{Model without repayment - experiments with different values of the credit limit}

Model behavior is tested with different values of the credit limit $(\$ 2,000, \$ 6,000$ and $\$ 12,000)$, and it is going to be presented in the following part of the paper. 
The above values were used as a proxy for three different levels of credit limit: low, middle and high.

Balance Payable grows slowly and slowly and it reaches the equilibrium value in the 50th month (Figure 3). As expected, the equilibrium value is the highest for CREDIT LIMIT of $\$ 12,000$, and the lowest for CREDIT LIMIT of $\$ 2,000$. Balance Payable is part of a negative feedback loop: Balance Payable available credit credit card purchases. Available credit is the difference between the credit limit and the Balance Payable. In other words, credit limit is the goal of a negative feedback loop, and Balance Payable will always reach the equilibrium value equal to the credit limit. In other words, an individual will spend as much money as he or she has available in the form of the credit limit. The behavior of interest on balance is the same (Figure 4).

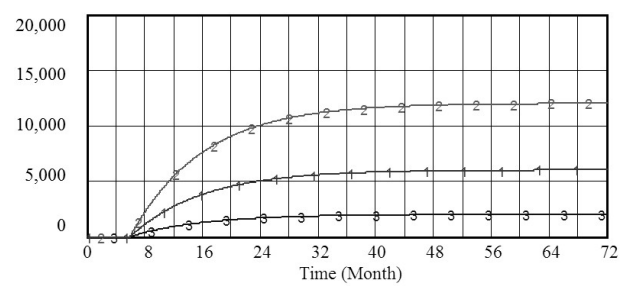

Balance Payable : credit limit - $\$ 6000-1,1,1,1$, dollars Balance Payable : credit limit - $\$ 12000=2 \quad 2 \quad 2 \quad 2 \quad 2 \quad z$ dollars Balance Payable : credit limit $-\$ 2000$ s $33_{3} 3_{3} 3_{3} 3_{-}$dollars Figure 3: The effect of changes in CREDIT LIMIT on Balance Payable

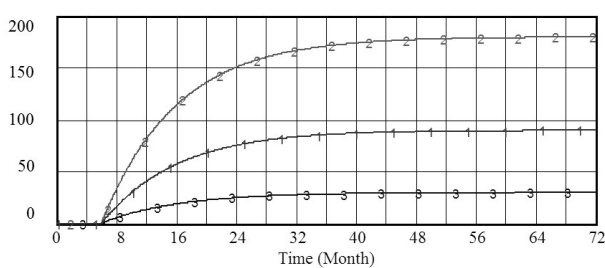

interest on balance : credit limit $-\$ 6000 \longrightarrow$ dollars/Month

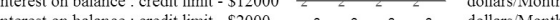

Figure 4: The effect of changes in CREDIT LIMIT on interest on balance

The overall behavior of credit card purchases is the same for different values of CREDIT LIMIT - at first it jumps after an individual receives his or her credit card, and after that CREDIT LIMIT decreases slowly and slowly until it reaches the equilibrium of $\$ 0$ (Figure 5). The only difference is that credit card purchases in the 6 th month reach the highest value for CREDIT LIMIT of $\$ 12,000$. This is because credit card purchases are set to $10 \%$ of the available credit. Therefore, although an individual always spends the same percent of his or her available credit, the absolute value is higher for higher values of CREDIT LIMIT. The behavior of the available credit is the same (Figure 6).

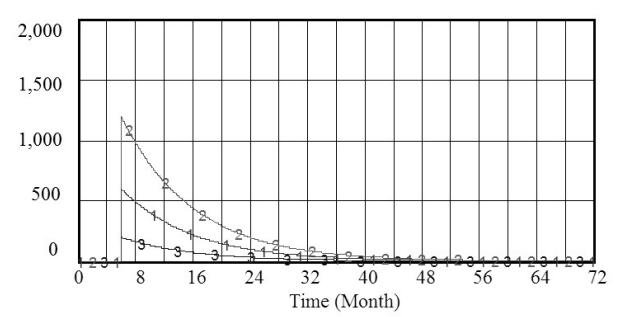

credit card purchases : credit limit - \$6000, , , dollars/Month credit card purchases : credit limit $-\$ 1200022 \quad$ dollars/Month

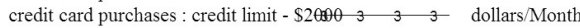

Figure 5: The effect of changes in CREDIT LIMIT on credit card purchases

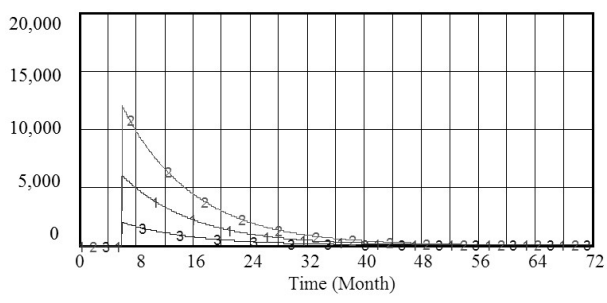

available credit : credit limit $-\$ 6000,+,,,,,+$, dollars available credit : credit limit - $\$ 12000=2 l_{2}^{2} \quad 2 \quad 2 \quad 2$ dollars

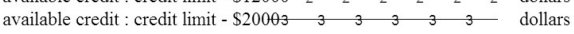

Figure 6: The effect of changes in CREDIT LIMIT on available credit 
Cash purchases decrease slowly and slowly until they reach the equilibrium value, which is the lowest for the highest value of CREDIT LIMIT (Figure 7). This is because cash purchases are the difference between PAYCHECK and the interest on balance. The interest on balance is the highest for the highest value of CREDIT LIMIT (because an individual always uses the entire CREDIT LIMIT available), and therefore cash purchases are the lowest for the highest value of CREDIT LIMIT.

Again, the budget available for spending jumps for a while when an individual receives his or her credit card, but in the long run budget the available for spending is lower than without the credit card. For different values of CREDIT LIMIT the budget available for spending behaves in the same way. But, for the highest value of CREDIT LIMIT the budget available for spending is at first the highest and in the long run the lowest (Figure 8).

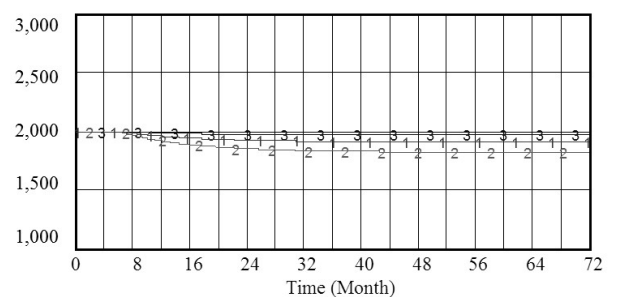

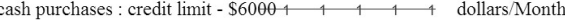
cash purchases : credit limit $-\$ 120002{ }_{2}^{2}{ }_{2}^{2}{ }^{2}$ dollars/Month

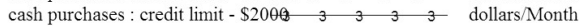

Figure 7: The effect of changes in CREDIT LIMIT on cash purchases

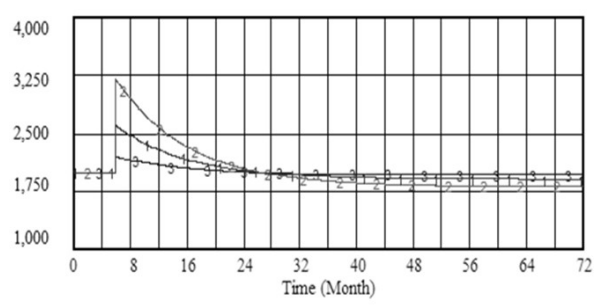

budget avalable for spending : credit limit - $\$ 6000+1+1+$ dollars Month budget avalable for spending : credit limit - $\$ 12000 \quad \mathrm{z}_{2} \mathrm{z}_{2}-\mathrm{2}$ dollars Month budget avalable for spending : credit limit - $\$ 2000 \longrightarrow$ C Figure 8: The effect of changes in CREDIT LIMIT on budget available for spending

\subsection{Model with repayment - model behavior}

We have presumed that after four years (48 months) an individual decides to gradually eliminate his or her account balance. Such a period is used as a presumption that the credit card owner is a student who repays his or her debt after graduation. At that moment, the balance has reached the limit and an individual continuously pays off the interest charges on the balance and the balance itself stays constant.

Individual's policy is to spend a fixed fraction of the available credit called a spending fraction each month. The available credit is the difference between the maximum balance allowed - credit limit and the current Balance Payable. If an individual repays the entire balance each month, his or her available credit will be equal to the credit limit. An individual decides to repay his or her debt to the Credit Card Company and he or she decides to repay every month the amount equal to CREDIT LIMIT . SPENDING FRACTION. An individual has chosen this amount because if he or she has no balance, he or she would spend exactly this amount.

On month 48 , individual's Balance Payable is $\$ 6,000$ and he or she decided to repay $\$ 600$ every month. If he or she stopped making his or her credit card purchases, he or she would repay the debt after 10 months. But, an individual repays $\$ 600$ each month plus the interest on balance. Therefore, Balance Payable gradually decreases and the available credit increases, and he or she can spend some money on credit 
card purchases (Figure 9). As Balance Payable gradually decreases, the interest on balance also decreases slowly and slowly until it reaches the equilibrium of $\$ 0$ after 96 months (Figure 10).

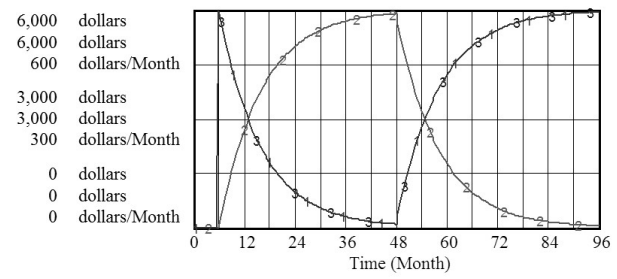

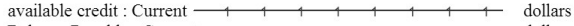

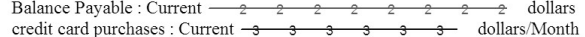

Figure 9: Behavior of Balance Payable, available credit and credit card purchases after individual decides to repay his/her debt

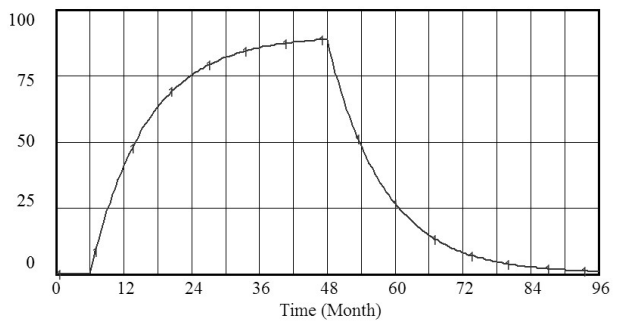

interest on balance : Current $+, 1,1,1$, dollars/Month

Figure 10: Behavior of interest on balance after he or she decides to repay his or her debt

Before month 48 cash purchases were at the equilibrium value of $\$ 1,911$ which is equal to the difference between the paycheck of $\$ 2,000$ and the equilibrium value of the interest rate of $\$ 89$. Cash purchases drop in month 48 , because an individual repays $\$ 600$ every month. At first they drop to $\$ 1,311$, but after that they start to increase slowly and slowly until all the balance is repaid and the interest on balance is 0 , i.e. when they reach the equilibrium value of $\$ 1,400(\$ 2,000-\$ 600)$ (Figure 11).

The budget available for spending depends on cash purchases and credit card purchases. The budget available for spending reaches the equilibrium value of $\$ 1,920$ in month 48 , and it drops to $\$ 1,320$ because an individual repays $\$ 600$ each month. At that point he or she almost did not have any credit card purchases. As an individual repays his or her balance, his or her cash purchases rise (because the interest rate on a smaller balance is also smaller) and his or her credit card purchases rise (because the available credit is bigger). Therefore, his or her budget available for spending increases slowly and slowly until it reaches equilibrium of $\$ 2,000$, which is equal to individual's paycheck (Figure 12).

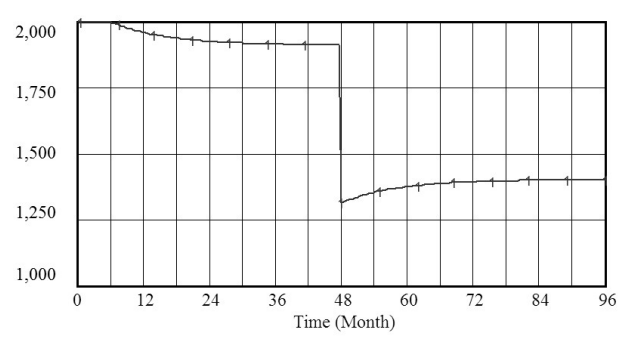

cash purchases: Current $\longrightarrow$, , , , , , , dollars/Month

Figure 11: Behavior of cash purchases after an individual decides to repay his or her debt

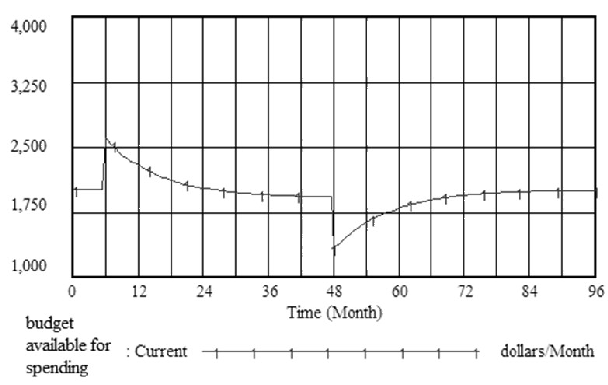

Figure 12: Behavior of budget available for spending after an individual decides to repay his or her debt 


\subsection{Summary of model behavior and results}

The system dynamics model has been used in order to explore the impact of credit limit on the long-term budget available for spending measured in terms of the total amount of money a person can spend at any time. Experiments with the model have been conducted based on the proposition that the individual will spend the total amount of credit limit, as proved by [22]. Results of our research are consistent with Ratha conclusions [20] and indicate that the long-term budget available for spending deteriorates in case of the assumptions stated above. The findings of our model are consistent with the previous findings which indicate that individuals tend to spend as much money on credit card as approved to them and do not tend to return money already spent if it is not demanded by the credit card issuer, so the debt gets higher and higher [26, 18]. However, there are also consumers who use credit cards in order to reallocate their income and plan their future expenses [26]. Regarding the fact that the spending habits are created early in life, counseling on credit card usage should preferably be included in student education [14].

\section{Simulation game for credit card repayment}

In this section we present a simulation game for the model explained above. We have designed the simulation game based on the Ratha's model [20]. The simulation game can be played with the objective to investigate the consequences of the problem concerning the personal credit card limit and the budget available for spending. We have decided to use four control variables (paycheck, credit limit, spending fraction and interest rate) that showed the greater impact on the budget available for spending. The players are encouraged to increase the budget available for spending with experimenting different values of control variables.

The game begins with a discussion about the personal financial indiscipline and how it influences the budget available for spending of the credit card owner. Then, the system dynamics model of the budget available for spending is presented. Players play the game for one or two hours. The goal of the game is to target the highest budget available for spending, and in the same time not to go through the credit limit. Every six months players make the decisions on the credit limit and the spending fraction. Values for paycheck and interest rates are also determined by the Slider Inputs, but are estimated by the game administrator.

The consequences of player's decisions are presented on the control panel of the game and on the graph. Players monitor the budget available for spending. From one hypothetical play of the game it is available that the budget available for spending reached the equilibrium value of $\$ 1,920$ in month 48 , and it drops to $\$ 1,320$, because an individual repays $\$ 600$ each month. During the next several months an individual repays his or her balance, which resulted in rising of credit card purchases. The budget available for spending continues to increase slowly until it reaches equilibrium of $\$ 2,000$ (Figure 13). 


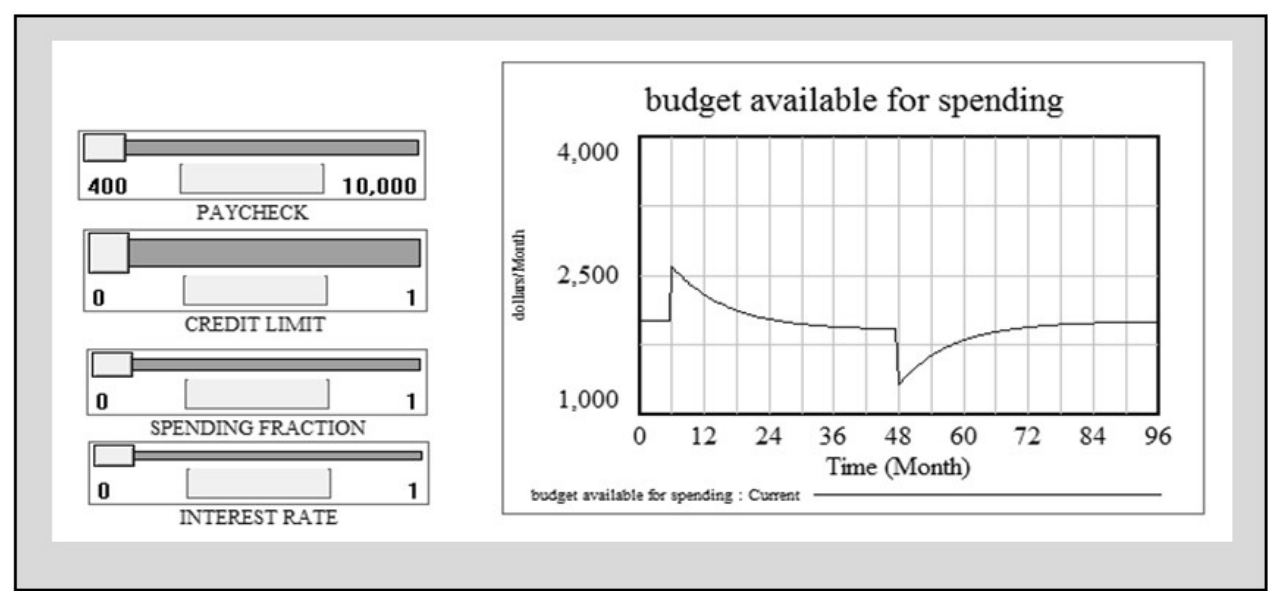

Figure 13: Control panel of the game

\section{Conclusion}

Results of our research indicate that the long-term budget available for spending deteriorates in case of the above aforementioned assumptions, and are applicable to both developed and developing countries due to the fact that previous research suggest that not only the level of countries development impacts the behavior of the credit card owner, but also personal characteristics like income [5], social class [25], and age $[22,17,18]$. There are several practical implications and lessons learned from the model. First, if an individual borrows some money on his or her credit card, he or she will have a higher budget available for spending for a limited time. In the long run, it will be very hard for him or her to repay the debt because for a long time his or her budget available for spending will be low. Second, an individual has to be very persistent in order to survive while his or her budget available for spending is low (in the short run) until it rises (in the long run), because he or she is tempted all the time with a large credit limit of the approved amount. However, such behavior is hardly typical since individuals are not likely to be highly-disciplined when it comes to personal finance. Third, results of our research indicate that banks are in a position to make substantial earnings from the flexible credit arrangements. On the other hand, banks and credit card issuers have to take into account credit card owners' typical behavior in order to effectively manage exposure at default (EAD), which is regulated at the Basel 2 level [10].

Limitations of our research stem mainly from the fact that there are additional forms of consumer credit (e.g. overdraft loans and installment payments schemes). In addition, research has been conducted with the presumption that the credit card owner will use the entire credit limit available, which is a typical behavior of a credit card owner according to [21], but there are exceptions that could be taken into consideration in further research. Nonetheless, there are possible lessons for future research. For example, future models could be used for making conclusions about the impact of the credit card spending limit on the long-term personal financial resources and compare upon with financial state of developed and developing coun- 
tries. Further research should be also oriented towards detection of a long term debt and usage of credit cards due to several predictors: situational variables, personality characteristics, financial education and family situation.

\section{References}

[1] Abdul-Muhmin, A.G., Umar, Y.A. (2007). Credit Card Ownership and Usage Behavior in Saudi Arabia: The Impact of Demographics and Attitudes toward Debt. Journal of Financial Services Marketing, 12(3), 219-234.

[2] Bauer, M., Auer-Srnka, K.J. (2012). The Life Cycle Concept in Marketing Research. Journal of Historical Research in Marketing, 4(1), 68-96.

[3] Bianchi, C. (2002). Introducing SD Modeling into Planning and Control Systems to Manage SMEs' Growth: A Learning-Oriented Perspective. System Dynamics Review, 18(3), 315-338.

[4] Buchmeister, B. (2008). Investigation of the Bullwhip Effect Using Spreadsheet Simulation, International Journal of Simulation Modelling, 7(1), 29-41.

[5] Chan, R.Y. (1997). Demographic and Attitudinal Differences between Active and Inactive Credit Cardholders The Case of Hong Kong. International Journal of Bank Marketing, 15(4), 117-125.

[6] Chien, Y.W., Devaney, S.A. (2001). The Effects of Credit Attitude and Socioeconomic Factors on Credit Card and Instalment Debt. The Journal of Consumer Affairs, 35(1), $162-179$.

[7] Crnkovic, J. (2013). The Future of CRM is UX. Business Systems Research, 4(1), $4-13$.

[8] Danes, S.M., Hira, T.K. (1990). Knowledge, Beliefs, and Practices in the Use of Credit Cards. Home Economics Research Journal, 18(3), 223-235.

[9] Hayhoe, C.R., Leach, LJ., Turner, P.R., Bruin, M.J., Lawrence, F.C. (2000). Differences in Spending Habits and Credit Use of College Students. The Journal of Consumer Affairs, 34(1), 113-133.

[10] Herring, R.J. (2004). The Subordinated Debt Alternative to Basel II. Journal of Financial Stability, 1(2), 137-155

[11] Joo, S.H., Grable, J.E., Bagwell, D.C. (2003). Credit Card Attitudes and Behaviors of College Students. College Student Journal, 37(3), 405-419.

[12] Kaynak, E., Harcar, T. (2001). Consumers' Attitudes and Intentions towards Credit Card Usage in an Advanced Developing Country. Journal of Financial Services Marketing, 6(1), 24-39.

[13] Ljoljic, B.; Katalinić, B., Stuja, K. (2002). Optimization of Flexible Assembly System Using Simulation. International Journal of Simulation Modeling, 1(1), 16-22.

[14] Merkac Skok, M., Dolinšek, T. (2013). Some Findings on Career Counseling in Higher Education. Journal of Enterprising Communities: People and Places in the Global Economy, 7(1), 81-94.

[15] Meško Štok, Z., Markič, M., Bertoncelj, A., Meško, M. (2010). Elements of Organizational Culture Leading to Business Excellence. Zbornik radova Ekonomskog fakulteta Rijeka, 28(2), 303-318.

[16] Morecroft, J.D.W. (1983). System Dynamics: Portraying Bounded Rationality. Omega, 11(2), 131-142.

[17] Norvilitis, J.M., MacLean, M.G. (2010). The Role of Parents in College Students' Financial Behaviors and Attitudes. Journal of Economic Psychology, 31(1), 55-63. 
[18] Norvilitis, J.M., Szablicki, P.B., Wilson, S.D. (2003). Factors Influencing Levels of Credit-Card Debt in College Students'. Journal of Applied Social Psychology, 33(5), 935-947.

[19] Pejic Bach, M. (2003). Surviving in an Environment of Financial Indiscipline: A Case Study From a Transition Country. System Dynamics Review, 19(1), 47-74.

[20] Ratha, M. (1997). The Credit Card Model. Massachusetts Institute of Technology, http://clexchange.org/ftp/documents/Roadmaps/RM9/D-4683-2.pdf [Accessed on 15 August 2013]

[21] Scholnick, B., Massoud, N., Saunders, A. (2013). The Impact of Wealth on Financial Mistakes: Evidence from Credit Card Non-Payment. Journal of Financial Stability, $9(1), 26-37$.

[22] Soman, D., Cheema, A. (2002). The Effect of Credit on Spending Decisions: The Role of the Credit Limit and Credibility. Marketing Science, 21(1), 32-53.

[23] Sterman, J. (2001). Business Dynamics: Systems Thinking and Modeling for a Complex World, McGraw-Hill/Irwin, New York.

[24] Wang, L., Lu, W., Malhotra, N.K. (2011). Demographics, Attitude, Personality and Credit Card Features Correlate with Credit Card Debt: A View from China. Journal of Economic Psychology, 32(1), 179-193.

[25] Wickramasinghe, V., Gurugamage, A. (2009). Consumer Credit Card Ownership and Usage Practices: Empirical Evidence from Sri Lanka. International Journal of Consumer Studies, 33(4), 436-447.

[26] Wong, N., Matthews, C. (2005). Cardholder perception of credit card limits, 10th AIBF Banking and Finance Conference, Melbourne, Australia.

[27] Zoroja, J. (2010). Simulation Games and Their Use at Business Educational Institutions in the Republic of Croatia. The Business Review, Cambridge, 15(1), 113-118. 